\title{
Metabolism of a subtidal rocky mussel reef in a high-temperate setting: pathways of organic $\mathrm{C}$ flow
}

\author{
Karl M. Attard ${ }^{1,2, *}$, Iván F. Rodil ${ }^{1,3}$, Peter Berg ${ }^{4}$, Andrew O. M. Mogg ${ }^{5}$, \\ Mats Westerbom ${ }^{1}$, Alf Norkko ${ }^{1,3}$, Ronnie N. Glud ${ }^{2,6}$ \\ ${ }^{1}$ Tvärminne Zoological Station, University of Helsinki, J.A. Palménin tie 260, 10900 Hanko, Finland \\ ${ }^{2}$ Department of Biology, University of Southern Denmark, 5230 Odense M, Denmark \\ ${ }^{3}$ Baltic Sea Centre, Stockholm University, 10691 Stockholm, Sweden \\ ${ }^{4}$ Department of Environmental Sciences, University of Virginia, 291 McCormick Road, Charlottesville, VA 22904-4123, USA \\ ${ }^{5}$ Tritonia Scientific, Dunstaffnage Marine Laboratories, Oban, Argyll PA37 1QA, UK \\ ${ }^{6}$ Department of Ocean and Environmental Sciences, Tokyo University of Marine Science and Technology, 26 108-8477 Tokyo, Japan
}

\begin{abstract}
Mytilid mussels form abundant, species-rich reefs on rocky substrates, but the role of this key habitat in carbon (C) cycling remains poorly understood. We performed a seasonal study on a $5 \mathrm{~m}$ deep photic Mytilus trossulus reef in the Central Baltic Sea to investigate pathways and rates of organic C flow. Reef gross primary production (GPP) and respiration $(R)$ were estimated seasonally using underwater $\mathrm{O}_{2}$ eddy covariance on hourly and daily timescales. Photogrammetry and biotic sampling were used to quantify reef rugosity and mussel coverage, and to derive mussel filtration and biodeposition. Mussels were highly abundant, reaching $\sim 50000 \mathrm{ind} . \mathrm{m}^{-2}$, and the reef structure increased the seabed surface area by $44 \%$. GPP hourly was up to $20 \mathrm{mmol} \mathrm{O}_{2} \mathrm{~m}^{-2}$ $\mathrm{h}^{-1}$ and $\mathrm{GPP}_{\text {daily }}$ was up to $107 \mathrm{mmol} \mathrm{O}_{2} \mathrm{~m}^{-2} \mathrm{~d}^{-1}$, comparable to a nearby seagrass canopy. Hourly eddy fluxes responded linearly to light intensity and flow velocity, with higher velocities enhancing reef $\mathrm{O}_{2}$ uptake at night. Reef $R_{\text {daily }}$ exceeded GPP daily on 12 of 13 measurement days, and $R_{\text {annual }}\left(29 \mathrm{~mol} \mathrm{O}_{2} \mathrm{~m}^{-2} \mathrm{yr}^{-1}\right)$ was 3 -fold larger than $\mathrm{GPP}_{\text {annual }}$. The reef sustained a productive community of microbes and fauna whose activities accounted for $\sim 50 \%$ of $R_{\text {annual }}$. Horizontal water advection promoted food supply to the reef and likely facilitated substantial lateral $\mathrm{C}$ export of mussel biodeposits. Our analyses suggest that a reduction in mussel reef extent due to ongoing environmental change will have major implications for the transport and transformation of $\mathrm{C}$ and nutrients within the coastal Baltic Sea.
\end{abstract}

KEY WORDS: Primary production - Respiration - Biodiversity - Seafloor ecosystems . Oxygen fluxes $\cdot$ Carbon cycling $\cdot$ Metabolism $\cdot$ Baltic Sea

\section{INTRODUCTION}

Mytilid mussels are key habitat-forming species in temperate and high-latitude waters (Hilbish et al. 2000). Through their settlement and growth, mussels form complex 3-dimensional reefs that provide habitat structure for diverse and abundant benthic communities (Commito \& Rusignuolo 2000, Norling \& Kautsky 2008). Mussels enhance the transfer rate of suspended particulate matter from the water column

${ }^{*}$ Corresponding author: karl.attard@biology.sdu.dk to the seabed through active filtration, enriching the near-bed environment with biodeposits that allow reef-associated communities of microbes and fauna to flourish (Kautsky \& Evans 1987, Norling \& Kautsky 2007, Heisterkamp et al. 2013). High seabed surface roughness and mussel siphonal jets enhance turbulent mixing and rapidly exchange bioavailable nutrients such as $\mathrm{NH}_{4}{ }^{+}$and $\mathrm{PO}_{4}{ }^{3-}$, sustaining new phytoplankton production (Butman et al. 1994, Prins \& Smaal 1994, Nishizaki \& Ackerman 2017). In light-

(C) The authors 2020. Open Access under Creative Commons by Attribution Licence. Use, distribution and reproduction are unrestricted. Authors and original publication must be credited. 
exposed reefs, phototrophic communities of microphytobenthos and macroalgae may provide a significant additional source of autochthonous organic matter, contributing directly to oceanic primary production and bolstering carbon (C) flow to higher trophic levels (Kautsky \& Wallentinus 1980, Norling \& Kautsky 2007, Kotta et al. 2009). Considerable research has gone into determining the ecological and functional roles of marine mussels, but their importance for coastal C cycling (primary production and respiration) on spatial and temporal scales of the entire reef community remains poorly understood. This is especially the case for mussel reefs located on rocky substrates, despite these being characteristic of many temperate and high-latitude coastal settings.

The Baltic Sea constitutes a compelling geographic region to investigate metabolism associated with mytilid reefs. In this high-temperate, strongly seasonal environment, the bay mussel Mytilus trossulus (Gould 1850) forms large continuous reefs on bare rock in the central and western parts of the Gulf of Finland at water depths down to $15 \mathrm{~m}$, although it is most abundant at shallower photic depths of $\sim 5 \mathrm{~m}$ (Westerbom et al. 2002). Mytilid reefs represent a key coastal habitat in the Baltic that sustain ecologically and commercially important fish such as European flounder Platichthys flesus and roach Rutilus rutilus, as well as migratory birds such as eiders Somateria mollissima (Ost \& Kilpi 1998, Westerbom et al. 2018). Although widespread, this habitat is located very near the minimum salinity required for successful reproduction of its foundation species ( $5 \mathrm{psu})$ (Kautsky \& Tedengren 1992). Regional climatic changes are projected to increase net precipitation in the Baltic catchment area by $\sim 20 \%$, increasing freshwater runoff and decreasing Baltic Sea salinity to levels where marine mussel reefs can likely no longer be sustained (Meier et al. 2012). Furthermore, surface water temperatures in excess of $25^{\circ} \mathrm{C}$ are increasingly being recorded in the Baltic (Siegel \& Gerth 2019). High water temperatures cause irreversible protein denaturation, reduce byssal thread production, and decrease the survival rate of $M$. trossulus larvae (Hofmann \& Somero 1995, Rayssac et al. 2010). The future of this key Baltic Sea habitat therefore seems uncertain (Vuorinen et al. 2015, Westerbom et al. 2019).

In this study, we investigated the role of shallow mytilid reefs in coastal C-flow pathways within the nearshore Baltic Sea. We estimated metabolic rates of a shallow rocky $M$. trossulus reef on a seasonal basis using the underwater eddy covariance $\mathrm{O}_{2}$ flux method (Berg et al. 2003), a recent technological development that allows investigating reef-scale $\left(10 \mathrm{~s}\right.$ of $\left.\mathrm{m}^{2}\right)$ meta- bolic rates and their drivers non-invasively at a high temporal resolution (1 h or less) (Berg et al. 2007, 2017). Using a series of multiple-day flux data sets, we investigated reef-scale metabolism and its relationship to key dynamic variables such as sunlight (photosynthetically active radiation, PAR) availability and water flow velocity in different seasons. The flux measurements were used to develop a simple predictive model to estimate reef metabolism continuously over $1 \mathrm{yr}$. These measurements were complemented with imaging techniques and biotic sampling to investigate reef surface roughness (rugosity), mussel coverage, and macrobenthic diversity associated with the reef. Our overall objective was to understand the ecological and biogeochemical function of this habitat on a reef-scale, in order to explore its importance for organic $\mathrm{C}$ cycling within its broader ecosystem that is undergoing rapid environmental change.

\section{MATERIALS AND METHODS}

\subsection{Study location and sampling}

Our study site was located near the Tvärminne Zoological Station in Hanko, on the southwest coast of Finland. We investigated a rocky outcrop located $\sim 5 \mathrm{~km}$ southwest of the research station $\left(59^{\circ} 47^{\prime} 43^{\prime \prime} \mathrm{N}\right.$, $23^{\circ} 14^{\prime} 44^{\prime \prime}$ E). This site was 1 of 6 habitats that were studied as part of a larger project investigating productivity of shallow benthic habitats of the Baltic Sea (Attard et al. 2019b). Submerged rocky outcrops are characteristic of the extensive Finnish coastline and Archipelago Sea. Although dwarfed by low salinity, mussels are still highly abundant in this region, reaching densities up to $\sim 100000$ ind. $\mathrm{m}^{-2}$, and annual monitoring data since 1996 indicates that individual reefs may persist for decades (Westerbom et al. 2019). We investigated a subtidal rocky plateau of $\sim 10 \times 10 \mathrm{~m}$ located at $\sim 5 \mathrm{~m}$ depth that was colonized by dense encrustations of Mytilus trossulus (Fig. 1). Benthic oxygen flux measurements and biological sampling were performed at this site over a period of $4-5 \mathrm{~d}$ on 4 occasions between June 2016 and August 2017 (June and October 2016, March and August 2017).

\subsection{Photogrammetry}

A digital surface model of a representative area of the mussel reef was created using 'structure from motion' photogrammetry, as described in Bayley et al. (2019). Photogrammetry provides a means to as- 

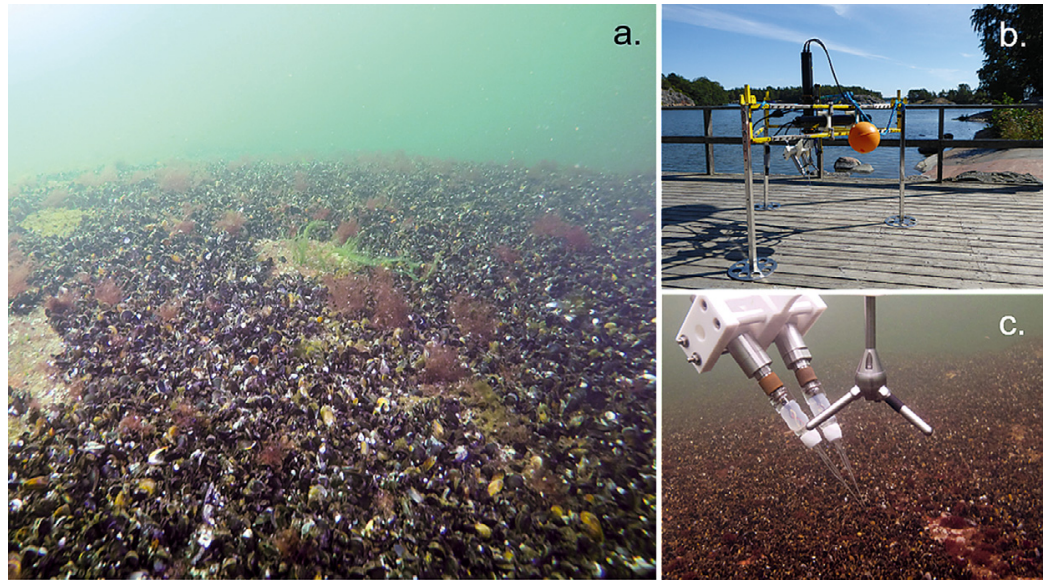

Fig. 1. (a) Underwater image of the Mytilus trossulus reef investigated in this study, (b) eddy covariance instrumentation ready to be deployed, and (c) a closeup of the eddy flux sensors deployed at the mussel reef. The mussels visible in (a) have a shell size of $\sim 3 \mathrm{~cm}$, and the leg height of the instrument in (b) is $80 \mathrm{~cm}$

sess the landscape perspective of the reef quantitatively, by providing measures of key features of the reef such as reef rugosity and mussel coverage. The reef section was photographed by divers under natural light using a compact camera (Sony RX100 Mk III) in a submersible housing. The model was based on the alignment of overlapping digital photographs. Photogrammetric processing was performed on Agisoft Metashape Professional software (Agisoft LLC 2017). Key processing steps included creating a dense XYZ point-cloud of over 6.3 million matched points and converting the point-cloud into a 389000 face Delaunay Triangulated Irregular Network mesh. In the program, alignment settings were set to 'high accuracy', depth filtering was set to 'moderate', and standard interpolation settings were applied. Tiled imagery was then overlaid onto the mesh, and in situ markers were used to calibrate the model to multiple known dimensions in XYZ space, giving an overall model accuracy of $<5 \mathrm{~mm}$. Mesh faces were $3 \mathrm{~mm}$, and resultant surface areas were derived from this resolution. Reef features smaller than $3 \mathrm{~mm}$ were therefore not represented within the model.

\subsection{Biological sampling}

We followed a sampling design described in detail in Rodil et al. (2019) to quantify dominant features of reef biodiversity within the eddy covariance flux footprint. Sampling was carried out by divers at the end of each eddy covariance deployment. A total of 8 weighted guidelines (5 m length) were placed on the seafloor in an octagon shape to delimit eight $45^{\circ}$ sections, with the eddy covariance instrument located at its centre. Samples were randomly collected from within each $45^{\circ}$ section $(\mathrm{n}=8)$ using a $20 \times 20 \mathrm{~cm}$ frame with a net bag designed especially for rocky substrates (Kautsky 1989). In the laboratory, the samples were sorted, and mussels were spread out even and thin on a sorting tray into 8 sectors. Four sectors were chosen at random and the mussels within these sectors were counted to estimate abundance (ind. $\mathrm{m}^{-2}$ ). For size distribution estimates, mussels were sorted into 4 size classes by sieving each sample through $1.0,2.0,4.0$, and $9.5 \mathrm{~mm}$ sieves (Westerbom et al. 2008). This approach is ideal for including small mussels, which are typically highly abundant and can otherwise be missed. The smallest mussels $(<1 \mathrm{~mm})$ were not considered. Although they likely occurred in large numbers between late August and early October (i.e. when new mussels settle), they would comprise just a small fraction $(<1 \%)$ of overall biomass and $<1 \%$ of reef filtration rates due to nonlinearity between mussel size and function (Riisgard et al. 2013). Following sieving, the length of $\sim 100$ individuals from each size class was measured using Vernier callipers to determine shell length along the maximum anterior-posterior axis. Dry weight $(g)$ was estimated from shell length as: meat weight $=$ shell length ${ }^{2.307} \times 10^{-4.744}$ (Westerbom et al. 2008). This approach does not consider other factors that may influence meat weight, such as spawning cycles, homeostatic energy loss, and food availability (Okumus \& Stirling 1998). Other (non-mussel) invertebrates associated with the reef were counted, identified, weighed (blot wet weight), and their biomass determined using conversion ratios for Baltic Sea invertebrates (Rumohr et al. 1987, Brey 2001). Macrofauna dry weight was converted to $\mathrm{C}$, assuming $50 \%$ organic $\mathrm{C}$ content (Wijsman et al. 1999).

\subsection{Mussel filtration and biodeposition}

Size-specific filtration (clearance) rates for $M$. edulis have been determined experimentally in previous studies, and the various allometric equations have been compiled by Riisgard et al. (2014). The filtration rate $\left(\mathrm{h}^{-1}\right)$ was estimated from body dry weight $(\mathrm{g})$ as: 
Filtration $=6.77 \times$ weight $^{0.68}\left(\mathrm{R}^{2}=0.94\right)$. This function was applied to convert data on mussel meat weight obtained from our biodiversity surveys to daily filtration rates $\left(\mathrm{m}^{-2} \mathrm{~d}^{-1}\right)$ for our 4 sampling dates. This was done by computing size-specific filtration rates, multiplying this value by abundance per size class, and summing all size classes to compute rates per $\mathrm{m}^{2}$ seabed. While this equation considers mussels of varying physiological condition, the approach does not account for seasonality (e.g. temperature effects) directly, nor does it account for the effects of dynamic in situ variables that may influence mussel feeding such as turbulent mixing and suspended particulate matter availability (Saurel et al. 2007).

Annual biodeposition ( $\mathrm{g} \mathrm{m}^{-2} \mathrm{yr}^{-1}$ organic C) was estimated from mussel biomass using the conversion ratios from Kautsky \& Evans (1987), who performed an extensive field study on a $5 \mathrm{~m}$ deep mussel reef in the Askö region in the Central Baltic Sea. Kautsky \& Evans (1987) quantified biodeposition in situ every month over an annual cycle using specially constructed sediment traps deployed over a period of 9-28 d, and deduced an annual biodeposition rate of $0.13 \mathrm{~g} \mathrm{C} \mathrm{g} \mathrm{g}^{-1}$ mussel (dry weight including shells). In our analysis, we estimated annual biodeposition ( $\mathrm{g} \mathrm{C}$ $\mathrm{m}^{-2} \mathrm{yr}^{-1}$ ) from the biomass-specific rates provided by that study, by multiplying the per gram rates by the mussel biomass we measured at our site.

\subsection{Eddy covariance deployments}

Fluxes were quantified in situ using our standard eddy flux systems that consisted of an acoustic Doppler velocimeter (ADV) (Vector; Nortek) and fastresponse oxygen microsensors with custom-made submersible amplifiers (McGinnis et al. 2011). Instrument configuration was very similar to the original design used by Berg \& Huettel (2008). The current meter was mounted in the centre of a sturdy lightweight tripod frame with its measurement volume located $\sim 15 \mathrm{~cm}$ above the seabed surface (Fig. 1c). The oxygen sensors were affixed to a polyoxymethylene holder that allowed the $\sim 20 \mu \mathrm{m}$ diameter microsensor tips to be accurately positioned $0.5 \mathrm{~cm}$ away from the measurement volume, using a measurement volume indicator for visual reference (Donis et al. 2015, Berg et al. 2016). The tripod was equipped with additional sensors for measuring seabed PAR (LI-192; Li-Cor), dissolved oxygen concentration (HOBO U26-001; Onset), salinity and temperature (HOBO U24-002-C; Onset) at 5 min intervals. The tripod was deployed from a small boat by divers, and a lift bag was used to carefully lower the instrument onto the seafloor and to orient the instrument within the predominant water flow direction (west to east). The velocimeter was programmed to sample with a delayed start to collect a measurement of the exact distance to the seabed. Following this measurement, the instrument logged current flow velocity and oxygen microsensor output in continuous sampling mode at $32 \mathrm{~Hz}$ over a period of $2-5 \mathrm{~d}$.

\subsection{Benthic oxygen fluxes}

Oxygen fluxes were extracted from the velocity and oxygen microsensor data following established guidelines (Lorrai et al. 2010, Donis et al. 2015). Our eddy covariance systems incorporated $2 \mathrm{O}_{2}$ microsensors for redundancy and cross-comparison. In post-processing, the 2 sensor signals were evaluated for their quality by (1) comparing the mean $\mathrm{O}_{2}$ microsensor concentration to the $\mathrm{O}_{2}$ optode, (2) evaluating point-to-point noise in the $8 \mathrm{~Hz}$ data streams, and (3) assessing linearity in the instantaneous cumulative fluxes for each $15 \mathrm{~min}$ flux period. The sensor showing the best characteristics was then used for flux extraction. The flux software SOHFEA (http:// sohfea.dfmcginnis.com/) was used to compute oxygen fluxes from the $32 \mathrm{~Hz}$ data using a multiple-step process described in detail in McGinnis et al. (2014). Turbulent fluctuations were isolated from a 90 s running mean for consecutive 15 min time intervals. One concern with selecting a time window of $90 \mathrm{~s}$ was for flux dampening at the low frequency scale (i.e. eddies with timescales $>90$ s might contribute significantly to the flux) (Volaric et al. 2018). We constrained potential flux loss by finding individual $15 \mathrm{~min}$ periods when the mean $\mathrm{O}_{2}$ concentration change for the whole $900 \mathrm{~s}$ period was small $(<3 \mu \mathrm{M})$, and could therefore be accurately accounted for using mean removal and linear regression. We then extracted a flux for this period detrended using a $900 \mathrm{~s}$ mean removal and linear regression, and $90 \mathrm{~s}$ running mean, and compared these results. From this analysis we deduced that flux loss was minimal ( $3 \%)$, and therefore proceeded to extract fluxes using a $90 \mathrm{~s}$ running mean. Following extraction, individual 15 min fluxes (units: $\mathrm{mmol} \mathrm{O}_{2} \mathrm{~m}^{-2} \mathrm{~h}^{-1}$ ) were quality-checked for anomalous variations. Large, spurious fluxes typically caused by jumps or spikes in the high-frequency oxygen concentration data were excluded from further analysis (Berg et al. 2013, Attard et al. 2014). Flux biases caused by sensor separation distances were estimated to be of minor importance in this study $(<8 \%)$ : 
physical separation between the microsensor and the velocimeter was small $(0.5 \mathrm{~cm})$, and the microsensors we used had a fast $90 \%$ response time of $\leq 0.3 \mathrm{~s}$ (Gundersen et al. 1998, Donis et al. 2015). Time-shift corrections were therefore not applied to the data. A planar fit rotation was used to transform the measured velocities into streamline coordinates (Lorke et al. 2013). Maximum flux bias caused by sensor stirring sensitivity for these data sets was estimated by Attard et al. (2019b) following the procedures described by Holtappels et al. (2015) and Berg et al. (2015) to be $<15 \%$ of the measured fluxes. The analysis by Attard et al. (2019b) assumed maximum flux bias contribution from all flow directions. Reanalysis of flow direction data indicates that these conditions occurred during $\sim 20 \%$ of the deployment duration and is therefore expected to be much smaller. A storage correction term was not applied to the data; the sensor measurement height was small $(\sim 0.15 \mathrm{~m})$, and maximum diel $\mathrm{O}_{2}$ concentration excursions in the bottom waters were $<20 \mu \mathrm{mol} \mathrm{l}^{-1}$. The 15 min eddy fluxes were subsequently bin-averaged to $1 \mathrm{~h}$ intervals for interpretation.

\subsection{Daily reef metabolism rates}

The time series of eddy fluxes were used to estimate daily rates of reef gross primary production $\left(\mathrm{GPP}_{\text {daily }}\right)$, respiration $\left(R_{\text {daily }}\right)$, and net ecosystem metabolism ( $\left.\mathrm{NEM}_{\text {daily }}\right)$ in mmol $\mathrm{O}_{2} \mathrm{~m}^{-2} \mathrm{~d}^{-1}$. For each flux data set, the quality-checked hourly eddy fluxes were separated into consecutive $24 \mathrm{~h}$ sections, with each section representing a period from midnight to midnight. The PAR data were used to identify daytime fluxes $\left(\right.$ FLUX $_{\text {dayi }}$ measured when PAR $\geq 1.0 \mu \mathrm{mol}$ $\mathrm{m}^{-2} \mathrm{~s}^{-1}$ ) and nighttime fluxes (FLUX $\mathrm{X}_{\text {nighti }}$ when PAR < $1.0 \mu \mathrm{mol} \mathrm{m}^{-2} \mathrm{~s}^{-1}$ ), as well as the duration of the daytime period in hours $\left(\mathrm{h}_{\text {day }}\right)$. GPP daily was computed as: $\mathrm{GPP}_{\text {daily }}=\left(\overline{\mathrm{FLUX}_{\text {day }}}+\left|\overline{\mathrm{FLUX}_{\text {night }}}\right|\right) \times \mathrm{h}_{\text {day }}, R_{\text {daily }}$ as $R_{\text {daily }}$ $=\left|\overline{\text { FLUX }_{\text {night }}}\right| \times 24$, and $\mathrm{NEM}_{\text {daily }}$ as the difference between GPP daily and $R_{\text {daily }}$ (Hume et al. 2011). The overbar indicates time-averaged values, and nighttime (negative) $\mathrm{O}_{2}$ fluxes were converted to their absolute value for interpretation. Note that a subset of the daily rates were presented in an earlier study (Attard et al. 2019b).

\subsection{Annual reef metabolism rates}

We developed a simple regression model between hourly eddy fluxes and near-bed sunlight availability (i.e. PAR) to estimate annual rates of GPP (GPP annual $)$, $R$ ( $\left.R_{\text {annual }}\right)$, and NEM (NEM annual $)$ at the mussel reef from the discrete seasonal flux measurements. This approach is similar to the one performed by Rheuban et al. (2014) for seagrass beds and Attard et al. (2015) for coralline algal beds. First, the relationship between hourly eddy fluxes and PAR was investigated using linear regression and light-saturation curves, and from regression analysis it was deduced that the best fits to the data in terms of the highest coefficient of determination ( $\mathrm{R}^{2}$ value) were obtained using linear regression. The fitting functions for the 4 seasonal flux data sets were applied to year-round estimates of hourly near-bed PAR. Year-round PAR at the reef was estimated from measurements of incoming PAR (Helsinki Kumpula Station, ID 101004, University of Helsinki) that were corrected for attenuation in water by applying attenuation factors that were determined in situ for different seasons during each measurement campaign. Attenuation factors were determined as the gradient of a least-squares linear regression that was fitted to incoming PAR data ( $x$-axis) plotted against seabed PAR ( $y$-axis). The duration of each season was defined in line with observations from the Finnish Meteorological Institute for the southwestern archipelago region (Spring: 15 Apr to 14 Jun; Summer: 15 Jun to 14 Sep; Autumn: 15 Sep to 14 Nov; Winter: 15 Nov to 14 Apr). The fitting functions were then applied to sections of near-bed PAR corresponding to the season in which they were measured. This process was repeated using fitting functions for $\mathrm{GPP}_{\text {hourly, where }}$ the hourly eddy fluxes were offset by the $R_{\text {hourly }}$ rate so that the $\mathrm{O}_{2}$ flux at $0 \mu \mathrm{mol}$ PAR $\mathrm{m}^{-2} \mathrm{~s}^{-1}$ was zero. $R_{\text {hourly }}$ was then computed as $R_{\text {hourly }}=\mathrm{GPP}_{\text {hourly }}-$ $\mathrm{NEM}_{\text {hourly }}$. The modelled fluxes were integrated over the year to compute $\mathrm{GPP}_{\text {annual, }} R_{\text {annual, }}$ and $\mathrm{NEM}_{\text {annual }}\left(\mathrm{mol} \mathrm{O}_{2} \mathrm{~m}^{-2} \mathrm{yr}^{-1}\right.$ ), and annual $\mathrm{C}$ equivalents were estimated from this using an $\mathrm{O}_{2}: \mathrm{CO}_{2}$ of 1.0 for GPP and $R$. The modelled fluxes likely overestimate the $R$ rate during early and mid-winter when light levels are very low, since high pelagic and reef primary production in late winter would stimulate night-time reef respiration. On the other hand, water temperature is higher in December $\left(3-4^{\circ} \mathrm{C}\right)$ than in March $\left(1-2^{\circ} \mathrm{C}\right)$ (Attard et al. 2019b), and this would counter some of the bias. For comparison, annual metabolism was also computed using a second approach, by integrating the discrete daily measurements for GPP, $R$, and NEM from the 4 measurement campaigns over the year. Regression analysis and numerical integration was performed in OriginPro 2019 (OriginLab Corporation). 
Table 1. Mean $( \pm \mathrm{SD})$ environmental conditions at the rocky mussel reef. Flow velocity was measured by a velocimeter $\sim 15 \mathrm{~cm}$ above the reef; $\mathrm{n}$ : number of $15 \mathrm{~min}$ measurements

\begin{tabular}{|lccccc|}
\hline $\begin{array}{l}\text { Sampling start } \\
\text { date }\end{array}$ & $\begin{array}{c}\text { Water temp- } \\
\text { erature }\left({ }^{\circ} \mathrm{C}\right)\end{array}$ & Salinity & $\begin{array}{c}\mathrm{O}_{2} \\
(\% \text { air sat. })\end{array}$ & $\begin{array}{l}\text { Flow velocity } \\
\left(\mathrm{cm} \mathrm{s}^{-1}\right)\end{array}$ & $\mathrm{n}$ \\
\hline 10 June 2016 & $10.7 \pm 0.9$ & $5.3 \pm 0.1$ & $88.9 \pm 3.4$ & $5.1 \pm 3.5$ & 411 \\
14 October 2016 & $10.7 \pm 0.1$ & $5.6 \pm 0.0$ & $83.9 \pm 0.4$ & $2.9 \pm 1.4$ & 265 \\
30 March 2017 & $1.6 \pm 0.1$ & $5.7 \pm 0.0$ & $88.9 \pm 2.7$ & $4.6 \pm 2.8$ & 467 \\
9 August 2017 & $14.7 \pm 0.8$ & $6.2 \pm 0.0$ & $85.5 \pm 3.7$ & $2.6 \pm 2.7$ & 341 \\
\hline
\end{tabular}

highest in October with mean $( \pm \mathrm{SE})$ values of $49000 \pm 3300$ ind. $\mathrm{m}^{-2}(\mathrm{n}=8)$, and biomass based on shell-free relationships similarly was highest at this time $\left(33.8 \pm 2.1 \mathrm{~g} \mathrm{C} \mathrm{m}^{-2}\right)$. Mussel density and biomass comprised $89-98 \%$ of the total reef macroinvertebrate community (Table 3). Crustaceans such as the marine isopod Idotea balthica and the amphipod Gammarus spp. comprised $2-10 \%$ of macroinvertebrate biomass, whereas polychaetes such as

\section{RESULTS}

\subsection{Reef environmental conditions}

Sampling was performed under a broad range of environmental conditions representing day-to-day variations and seasonal differences. Daily averaged $( \pm \mathrm{SD})$ water temperature ranged from $14.7 \pm 0.8^{\circ} \mathrm{C}$ ( $\mathrm{n}=341)$ in August to $1.6 \pm 0.1^{\circ} \mathrm{C}(\mathrm{n}=467)$ in March, and salinity was between 5.3 and 6.2 (Table 1). Dissolved $\mathrm{O}_{2}$ concentrations measured $\sim 15 \mathrm{~cm}$ above the reef indicated undersaturation year-round, with deployment means ranging from $83.9 \pm 0.4 \%(n=265)$ to $88.9 \pm 3.4 \%(\mathrm{n}=411)$ of air saturation (Table 1$)$. Near-bed daily PAR was highest in June $\left(8.1 \mathrm{~mol} \mathrm{~m}^{-2}\right.$ $\left.\mathrm{d}^{-1}\right)$ and lowest in October $\left(0.6 \mathrm{~mol} \mathrm{~m}^{-2} \mathrm{~d}^{-1}\right)$, with daily PAR varying up to 3 -fold between deployment days (Table 2).

\subsection{Reef photogrammetry model}

The scaled model of the reef allowed us to estimate the contribution of the mussels to small sub-cm scale variations in seabed surface amplitude (termed 'rugosity') (Fig. 2). The ratio between the 3-dimensional surface area and the 2-dimensional (geometric) area was 1.44, indicating that the mussels increased the surface area of the seabed - and thus the area over which biotic interactions and processes take place - by $44 \%$. Mussel coverage comprised $66 \%$ of the geometric surface area and $68 \%$ of the 3-dimensional surface area.

\subsection{Reef biodiversity, biomass, filtration, and biodeposition}

The number of reef macroinvertebrate taxa ranged seasonally from 9-12 (Table 3). Mussels were by far the most abundant macroinvertebrate species in terms of density and biomass. Mussel density was the ragworm Hediste diversicolor comprised 1-4\% . A substantial biomass of ephemeral macroalgae accumulated seasonally at the reef. This was highest in June (12.6 $\mathrm{g} \mathrm{C} \mathrm{m}^{-2}$ ), followed by August (8.2 $\mathrm{g} \mathrm{C} \mathrm{m}^{-2}$ ), and October (4.7 $\mathrm{g} \mathrm{C} \mathrm{m}^{-2}$ ). Macroalgal biomass was below detection in March (Table 3).

The mean $( \pm \mathrm{SD})$ derived filtration rates were $4.8 \pm$ $0.5 \mathrm{~m}^{3} \mathrm{~m}^{-2} \mathrm{~d}^{-1}$ in June, $4.1 \pm 0.6 \mathrm{~m}^{3} \mathrm{~m}^{-2} \mathrm{~d}^{-1}$ in October, $3.7 \pm 0.4 \mathrm{~m}^{3} \mathrm{~m}^{-2} \mathrm{~d}^{-1}$ in March, and $3.6 \pm 0.4 \mathrm{~m}^{3} \mathrm{~m}^{-2} \mathrm{~d}^{-1}$ in August ( $\mathrm{n}=8)$. Annual mussel biodeposition $\left(\mathrm{g} \mathrm{m}^{-2}\right.$ $\mathrm{yr}^{-1}$ organic C), estimated from biomass-specific rates using the conversion ratios from Kautsky \& Evans (1987), was $0.05 \mathrm{~kg} \mathrm{C} \mathrm{m}{ }^{-2} \mathrm{yr}^{-1}$.

Table 2. Daily bay mussel reef gross primary production (GPP), respiration $(R)$, and net ecosystem metabolism (NEM) calculated for consecutive $24 \mathrm{~h}$ periods of eddy covariance oxygen $\left(\mathrm{O}_{2}\right)$ fluxes, including deployment mean and 1 standard deviation $(\sigma)$, where available. Seabed photosynthetically active radiation (PAR) is presented as daily integrated values. Units are $\mathrm{mol} \mathrm{m}^{-2} \mathrm{~d}^{-1}$ for PAR; otherwise $\mathrm{mmol} \mathrm{O} \mathrm{O}^{-2} \mathrm{~d}^{-1}$

\begin{tabular}{|lcccccc|}
\hline & Day 1 & Day 2 & Day 3 & Day 4 & Mean & $\sigma$ \\
\hline Jun & & & & & & \\
GPP & 3 & 34 & 24 & 51 & 28 & 20 \\
$R$ & 51 & 69 & 72 & 65 & 64 & 9 \\
NEM & -48 & -34 & -48 & -14 & -36 & 16 \\
PAR & 6.1 & 7.4 & 9.0 & 9.6 & 8.0 & 1.6 \\
OCT & & & & & & \\
GPP & 10 & 0 & & & 5 & \\
$R$ & 76 & 55 & & & 65 & \\
NEM & -66 & -55 & & & -60 & \\
PAR & 0.8 & 0.6 & & & 0.7 & \\
Mar & & & & & & \\
GPP & & & & & & \\
107 & 47 & 103 & 25 & 70 & 41 & \\
$R$ & 109 & 89 & 67 & 54 & 80 & 24 \\
NEM & -2 & -43 & 36 & -29 & -9 & 35 \\
PAR & 2.3 & 0.8 & 2.8 & 1.9 & 1.9 & 0.8 \\
Aug & & & & & & \\
GPP & 64 & 55 & 19 & & 46 & 24 \\
$R$ & 134 & 125 & 76 & & 112 & 31 \\
NEM & -70 & -69 & -57 & & -65 & 7 \\
PAR & 7.3 & 8.3 & 4.8 & & 6.8 & 1.8 \\
\hline
\end{tabular}




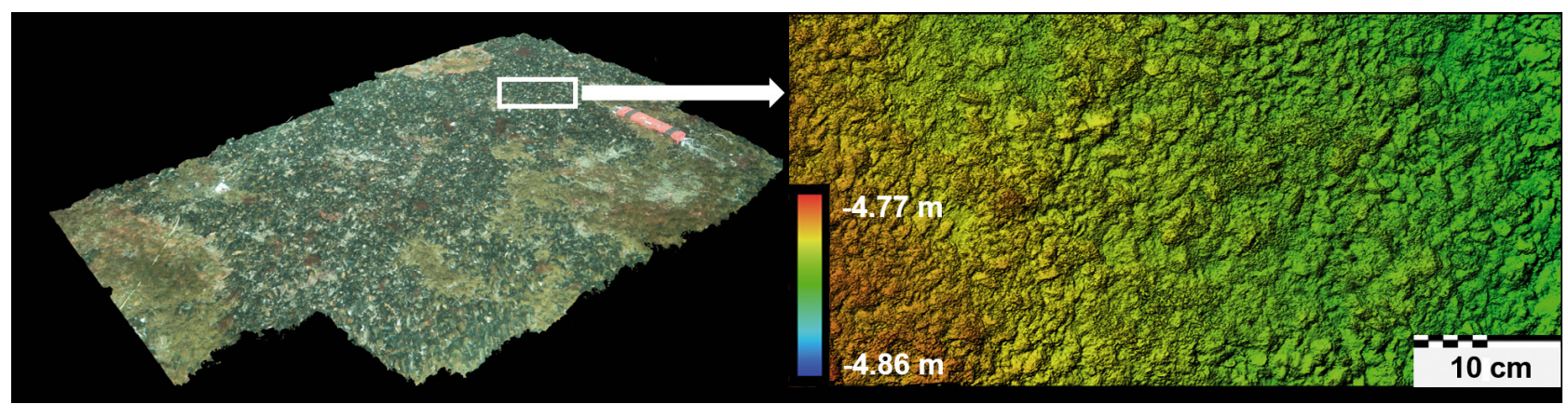

Fig. 2. An excerpt of the digital elevation model of the bay mussel reef created using 'structure from motion' photogrammetry, showing (a) a true-colour broad view of the reef, and (b) a section of the bathymetric model, showing small-scale variations in seabed surface topography created by the mussels

Table 3. Reef biomass and biodiversity, with mean ( \pm SE) bay mussel abundance and biomass $(\mathrm{n}=8)$. Numbers in brackets: mussel \% contribution to reef total. Mussel abundance was rounded to 2 significant digits

\begin{tabular}{|lcccc|}
\hline $\begin{array}{l}\text { Sampling } \\
\text { date }\end{array}$ & $\begin{array}{c}\text { Mussel } \\
\text { abundance } \\
\left.\text { (ind. } \mathrm{m}^{-2}\right)\end{array}$ & $\begin{array}{c}\text { Mussel } \\
\text { biomass } \\
\left(\mathrm{g} \mathrm{C} \mathrm{m}^{-2}\right)\end{array}$ & $\begin{array}{c}\text { Macro- } \\
\text { invertebrate } \\
\text { taxa (no.) }\end{array}$ & $\begin{array}{c}\text { Ephemeral } \\
\text { macroalgae } \\
\left(\mathrm{g} \mathrm{C} \mathrm{m}^{-2}\right)\end{array}$ \\
\hline Jun 2016 & $41000 \pm 3200(98)$ & $27.1 \pm 1.2(92)$ & 11 & 12.6 \\
Oct 2016 & $49000 \pm 3300(97)$ & $33.8 \pm 2.1(97)$ & 10 & 4.7 \\
Mar 2017 & $45000 \pm 4100(97)$ & $24.6 \pm 1.2(89)$ & 12 & 0.0 \\
Aug 2017 & $48000 \pm 6000(98)$ & $20.6 \pm 1.4(89)$ & 9 & 8.2 \\
\hline
\end{tabular}

\subsection{Hourly and daily reef metabolism}

The eddy covariance deployments produced 4 flux days in March and in June, $3 \mathrm{~d}$ in August, and $2 \mathrm{~d}$ in October (Table 2). During the day, short-term variations in eddy fluxes closely followed near-bed PAR dynamics, indicating that changes in the benthic activity were rapidly registered by the eddy flux sensors located $\sim 15 \mathrm{~cm}$ above the reef (Fig. 3a,b). At night, an increase in the mean flow velocity from 2$8 \mathrm{~cm} \mathrm{~s}^{-1}$ stimulated hourly reef $\mathrm{O}_{2}$ uptake by $\sim 3$-fold (from $\sim 3$ to $\sim 9 \mathrm{mmol} \mathrm{O}_{2} \mathrm{~m}^{-2} \mathrm{~h}^{-1}$ ) (Fig. 3e), documenting the dynamic nature of the $\mathrm{O}_{2}$ fluxes on a reef scale. Differences between daytime and night-time $\mathrm{O}_{2}$ fluxes were detected in all 4 measurement campaigns, documenting an active benthic primary production component. GPP daily was highest in March, up to $107 \mathrm{mmol} \mathrm{O}_{2} \mathrm{~m}^{-2} \mathrm{~d}^{-1}$, and was lowest in October (0 and $10 \mathrm{mmol} \mathrm{O}_{2} \mathrm{~m}^{-2} \mathrm{~d}^{-1}$ ) (Fig. 4). Reef GPP daily varied by up to 4 -fold between consecutive days (Table 2). Reef $R_{\text {daily }}$ exceeded $50 \mathrm{mmol} \mathrm{O}_{2} \mathrm{~m}^{-2} \mathrm{~d}^{-1}$ year-round, with the highest $R_{\text {daily }}$ of $134 \mathrm{mmol} \mathrm{O}_{2} \mathrm{~m}^{-2} \mathrm{~d}^{-1}$ measured in August (Table 2). Day-to-day $R_{\text {daily }}$ varied by up to 2-fold. Reef NEM daily was negative (net hetero- trophic) on 12 of the 13 measurement days (Fig. 5). On 2 days in March (Days 1 and 3), reef $\mathrm{GPP}_{\text {daily }}$ was comparable to or even exceeded $R_{\text {daily }}$ GPP daily was comparable to $R_{\text {daily }}$ on Day 1 (GPP daily: $R_{\text {daily }} \sim 1.0$ ), and was 1.5-fold larger on Day 3 (Table 2). Measurement days with the lowest $\mathrm{GPP}_{\text {daily }}$ also had the lowest $R_{\text {daily; }}$ this was consistent across seasons (Day 1 in June, Day 2 in October, Day 4 in March, and Day 3 in August; Table 2).

\subsection{Annual reef metabolism}

The $1 \mathrm{~h}$ eddy fluxes showed a significant and positive relationship with near-seabed PAR in all seasons (Fig. 6). The slope of the regression between the eddy fluxes and PAR was significantly different from zero at the $\alpha=0.05$ level, with the highest $\mathrm{R}^{2}$ value observed in March $\left(\mathrm{R}^{2}=0.74, \mathrm{p}<0.00\right)$, followed by June $\left(R^{2}=0.61, p<0.00\right)$, August $\left(R^{2}=0.17, p<0.00\right)$, and October $\left(R^{2}=0.07, p=0.04\right)$. Significance tests were performed using ANOVAs on $1 \mathrm{~h}$ flux data. Incident PAR was converted to near-bed PAR using attenuation coefficients determined in situ during the 4 measurement campaigns. These were 0.16 in June $\left(\mathrm{R}^{2}=0.94\right), 0.26$ in October $\left(\mathrm{R}^{2}=0.89\right), 0.12$ in March $\left(\mathrm{R}^{2}=0.95\right)$, and 0.18 in August $\left(\mathrm{R}^{2}=0.97\right)$. From the model we determined annual integrated rates of reef metabolism. These were GPP annual $=9.5 \mathrm{~mol} \mathrm{O}_{2} \mathrm{~m}^{-2}$ $\mathrm{yr}^{-1}, R_{\text {annual }}=29.4 \mathrm{~mol} \mathrm{O}_{2} \mathrm{~m}^{-2} \mathrm{yr}^{-1}$, and $\mathrm{NEM}_{\text {annual }}=$ $-19.9 \mathrm{~mol} \mathrm{O}_{2} \mathrm{~m}^{-2} \mathrm{yr}^{-1}$. These values compared well to annual estimates computed using a second approach of integrating the discrete daily measurements of GPP, $R$, and NEM over the year (Fig. 7). 


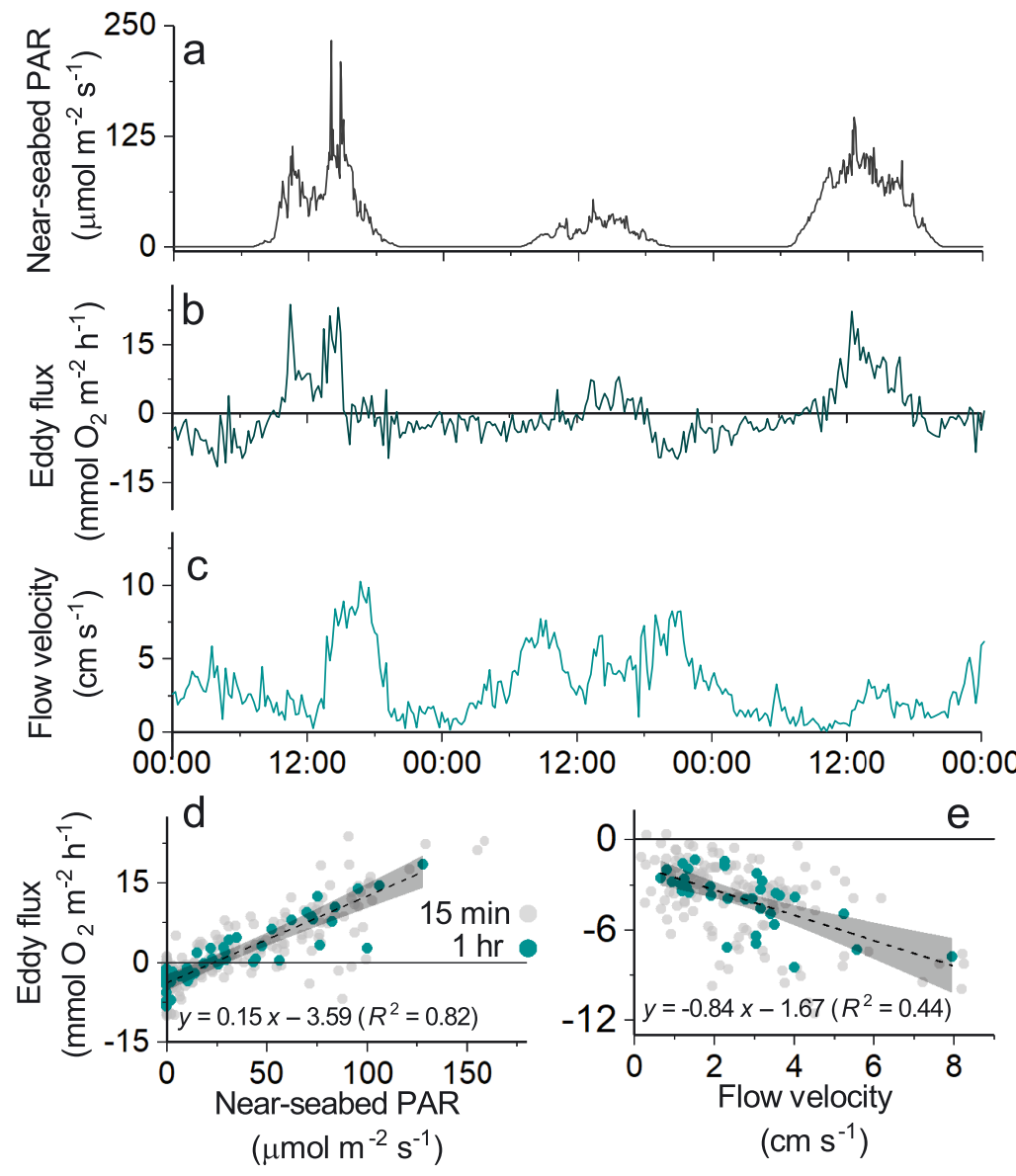

Fig. 3. Data from the eddy covariance instrument measured over 3 days in March, showing (a) near-seabed photosynthetically active radiation (PAR), (b) 15 min eddy fluxes, and (c) near-seabed flow velocity magnitude. (d) Eddy fluxes typically showed a tight coupling to PAR; (e) higher flow velocities stimulated the reef $\mathrm{O}_{2}$ uptake rate at night. In (d) and (e), dashed black lines: linear regressions; grey shading: $95 \%$ confidence bands
Investigation of $\mathrm{C}$-flow pathways aids in understanding how the reef functions, by determining the transport of $\mathrm{C}$ to the reef, its synthesis and transformation within the reef, and its export from the reef to the surrounding environment. Reef metabolism is a key C-flow pathway, but it remains challenging to quantify due to the rocky and uneven substrate as well as its dynamic nature. Literature values thus remain scarce. The aquatic $\mathrm{O}_{2}$ eddy covariance approach, originally proposed by Berg et al. (2003), has considerable advantages over other flux methods in habitats such as rocky mussel reefs, because it allows the quantification of reef-scale metabolism continuously over several days at a high temporal resolution and without interfering with key drivers of the metabolic signal such as light availability, flow velocity, and suspended matter concentrations (Berg et al. 2007, Rheuban \& Berg 2013). This approach provides detailed insight into the intricate patterns of reef primary production and respiration, and allows the daily balance between these 2 processes to be resolved, which is a key measure of whether the reef function serves as a net source or sink of organic matter, thus also indicating the degree to which such reefs rely on external sources of $\mathrm{C}$ such as phytoplankton.

\section{DISCUSSION}

Mytilid mussels are habitat engineers that alter the environment in which they settle in significant ways. In the Central Baltic Sea, low-salinity conditions has the effect of dwarfing mussels, which reach a maximum length of $\sim 35 \mathrm{~mm}$. However, mussels are still highly abundant, with densities of up to $\sim 50000$ ind. $\mathrm{m}^{-2}$ (Table 3) and form large reefs that add rugosity to the seabed and enhance organic matter deposition. The reefs that are created by mussels represent some of the most species-rich habitats in the Baltic Sea, and are of great ecological importance (Norling \& Kautsky 2008). Understanding how this key habitat functions on a reef scale therefore is important, especially within the context of ongoing environmental change, which is predicted to reduce mussel reef extent in the Baltic (Meier et al. 2012).

\subsection{Reef primary production}

The eddy covariance fluxes documented substantial primary production by the mussel reef on time. scales ranging from $1 \mathrm{~h}$ to $1 \mathrm{yr}$. GPP hourly was up to $20 \mathrm{mmol} \mathrm{O}_{2} \mathrm{~m}^{-2} \mathrm{~h}^{-1}$ and GPP daily was frequently between 50 and $100 \mathrm{mmol} \mathrm{O}_{2} \mathrm{~m}^{-2} \mathrm{~d}^{-1}$ in spring and in summer. In 2 instances, GPP daily was similar to or exceeded $R_{\text {daily }}\left(\mathrm{GPP}_{\text {daily }}: R_{\text {daily }} \geq 1.0\right.$; Table 2$)$. Similar observations of GPP daily: $R_{\text {daily }}$ close to 1.0 were made by Norling \& Kautsky (2007) in soft sediment mussel reefs in the Baltic using incubation techniques. The autochthonous $\mathrm{C}$ that is fixed by autotrophs present at the reef (microphytobenthos and transient accumulations of thin ephemeral macroalgae) represents a labile source of $\mathrm{C}$ that can be rapidly turned over to fuel secondary production at the reef or at surrounding depositional habitats (Miller et al. 1996). Days 

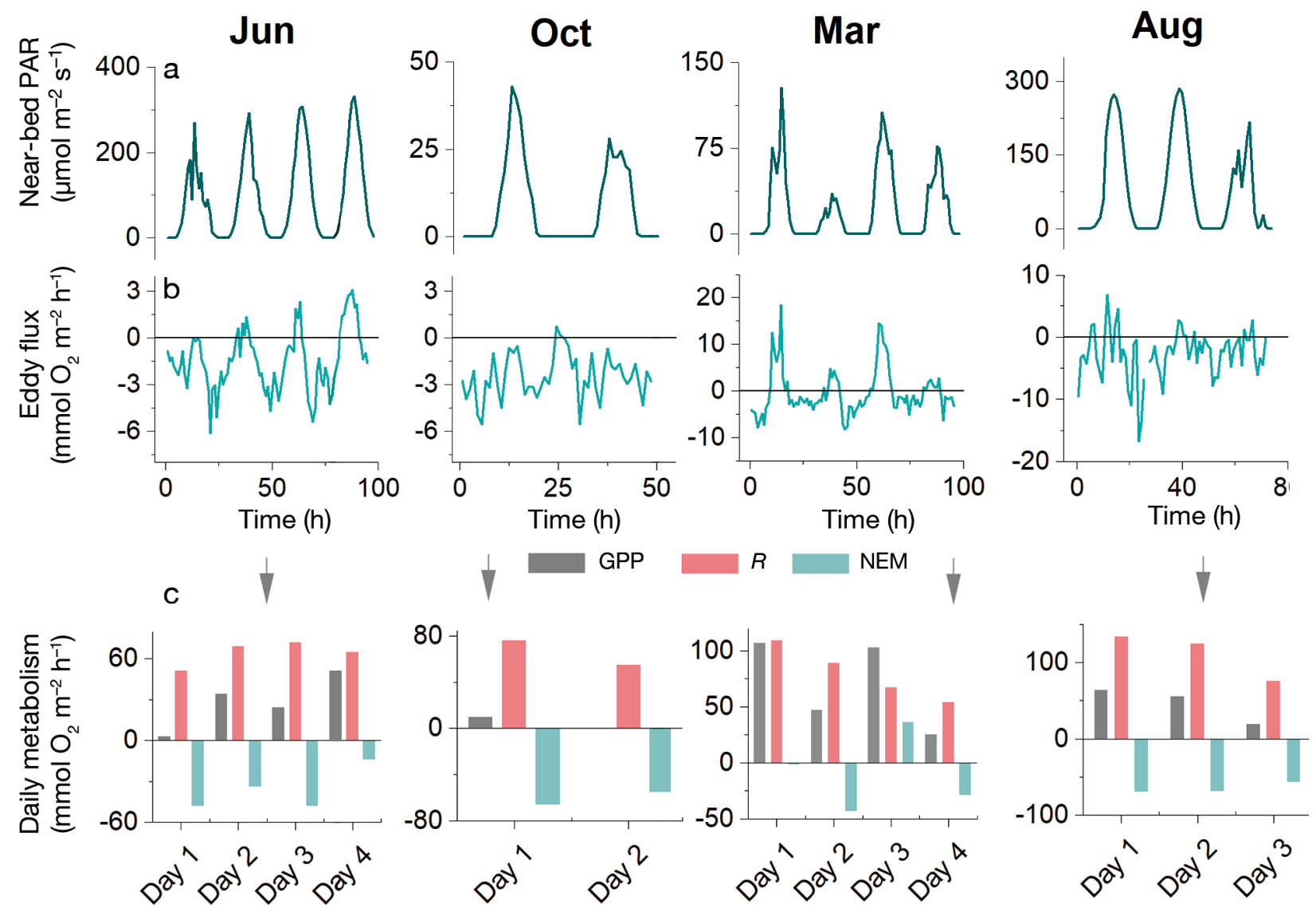

Fig. 4. (a) Near-seabed photosynthetically active radiation (PAR), (b) eddy covariance fluxes, and (c) daily metabolism rates for the 4 measurement campaigns at the bay mussel reef. GPP: gross primary production; $R$ : respiration; NEM: net ecosystem metabolism

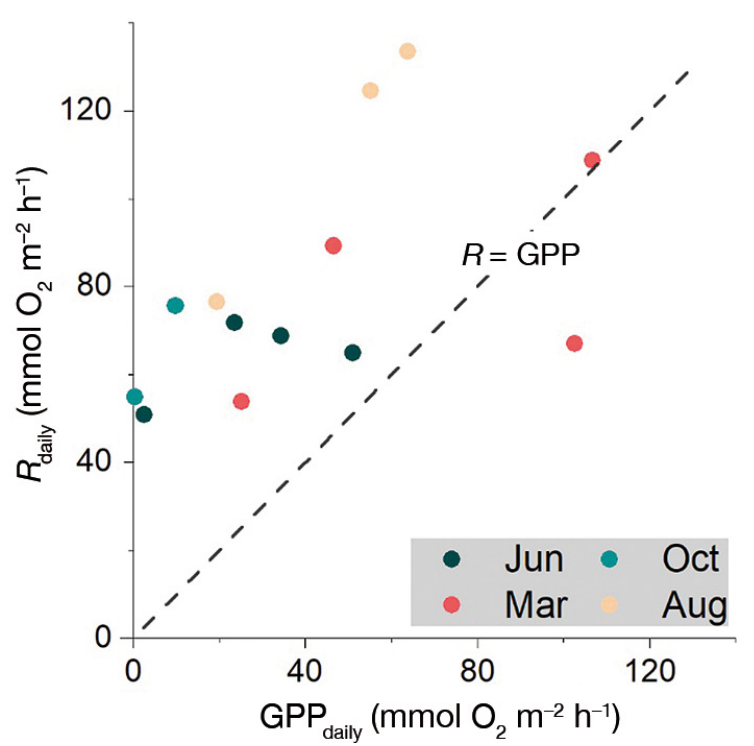

Fig. 5. Daily balance between daily bay mussel reef respiration $\left(R_{\text {daily }}\right)$ and gross primary production $\left(\mathrm{GPP}_{\text {daily }}\right)$ as determined from the eddy covariance fluxes in different seasons with the lowest $\mathrm{GPP}_{\text {daily }}$ also had the lowest $R_{\text {daily, }}$ potentially indicating tight autotroph-heterotroph coupling at the reef on timescales of $<24 \mathrm{~h}$ (Table 2).

The $\mathrm{GPP}_{\text {daily }}$ rates obtained in this study are comparable to rates obtained from a nearby seagrass canopy (Zostera marina) using eddy covariance (Attard et al. 2019b). Similar observations were made by Volaric et al. (2018) on intertidal oyster reefs in the Chesapeake Bay, USA. These results indicate that shallow invertebrate reefs, if present in high enough abundance, play a significant role in autochthonous organic matter production within the coastal zone, but this production pathway remains largely overlooked (Attard et al. 2019b). Indeed, high rates of reef primary production are surprising, given the low standing autotrophic biomass, which typically consists of microphytobenthos and tufts of ephemeral macroalgae (Fig. 1a), and the widespread observation that primary producer growth on rocky substrates often is strongly nutrient-limited (Elser et al. 2007). The linear relationships we observed between the hourly eddy fluxes 


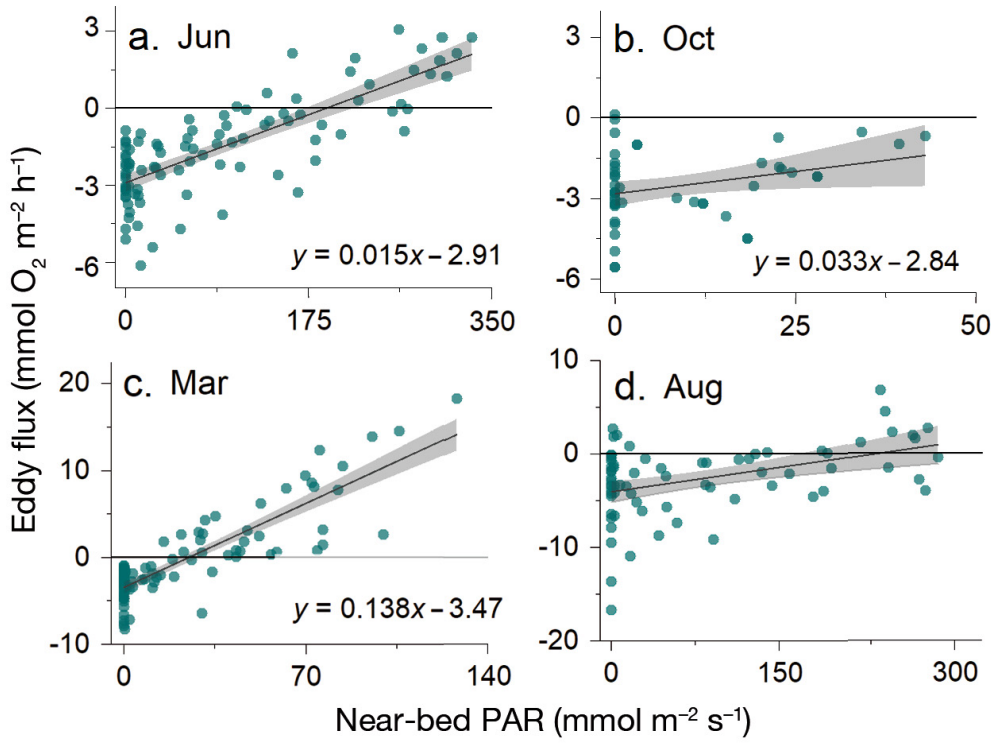

Fig. 6. Relationship between all measured hourly eddy fluxes and nearseabed photosynthetically active radiation (PAR) in (a) June, (b) October, (c) March, and (d) August. Least-squares linear regressions are fitted to the flux data; grey regions: $95 \%$ confidence bands
(Table 3), the highest rates of $\mathrm{GPP}_{\text {hourly }}$ and $\mathrm{GPP}_{\text {daily }}$ were measured in March, when macroalgal biomass was below detection (Table 2). In this case, the GPP signal was likely driven by microphytobenthos present as biofilms on mussel shells comprising $\sim$ two-thirds of seabed surface coverage, and on nearby rocky substrate. While we do not have direct measurements of microphytobenthos biomass, detailed microsensor measurements have documented considerable $\mathrm{O}_{2}$ production by biofilms on mussel Mytilus edulis shells, highlighting the importance of biofilms in overall reef functioning (Heisterkamp et al. 2013). The combined effects of increased 3-dimensional seabed surface area (rugosity) provided by mussels and the abundance of bioavailable nutrients makes shallow, light-exposed mussel reefs favourable habitats for primary production.

\subsection{Reef respiration}

and near-bed PAR suggest that primary production was not strongly nutrient-limited at our study site (Fig. 6), a result which may highlight the important role of marine mussels in engineering a nutrientrich benthic environment (Kautsky \& Wallentinus 1980). While seasonal accumulations of red and green macroalgae were evident at our study site, with summer standing autotrophic biomass of up to $13 \mathrm{~g} \mathrm{C} \mathrm{m}^{-2}$
Despite substantial GPP at the reef, $R_{\text {daily }}$ exceeded $\mathrm{GPP}_{\text {daily }}$ on 12 of 13 measurement days, and $R_{\text {annual }}$ was 3-fold larger than $\mathrm{GPP}_{\text {annual }}$ (Fig. 7). External input of organic material equivalent to at least $\sim$ twothirds of the annual reef $\mathrm{C}$ demand $\left(\mathrm{NEM}_{\text {annual }}=\right.$
Annual estimates from daily measurements
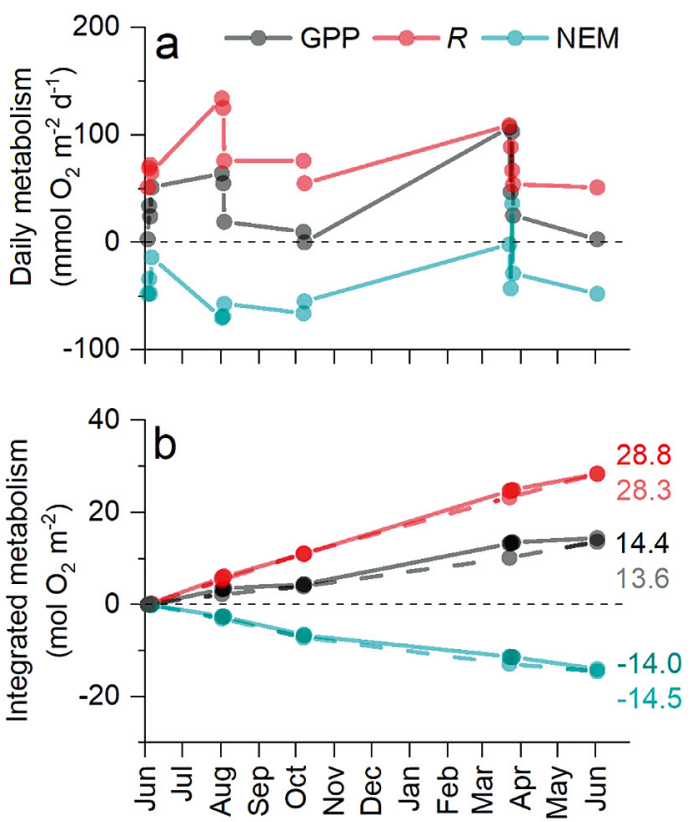

\section{Annual estimates from light-flux relationships}
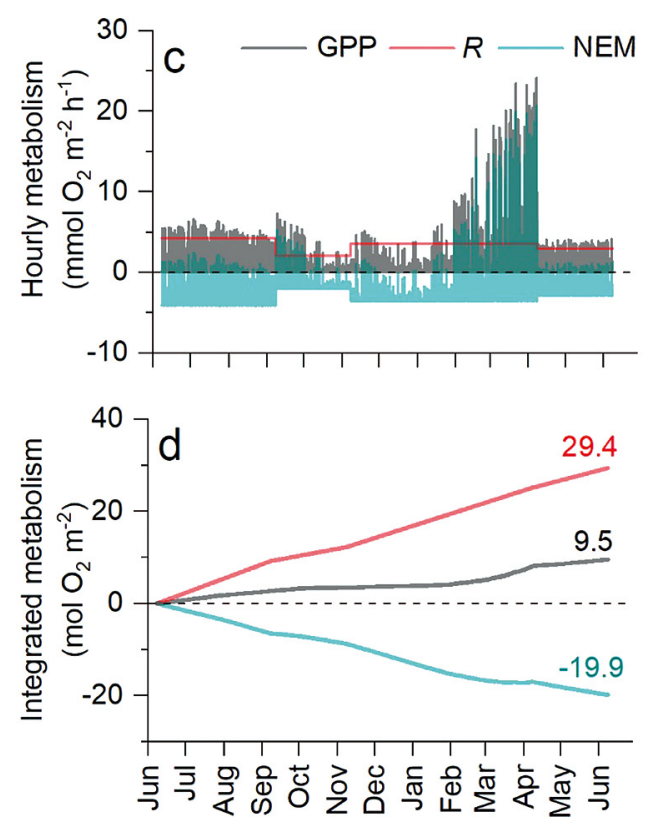

Fig. 7. Estimating annual bay mussel reef metabolism using 2 approaches: $(a, b)$ integration of measured daily rates (dashed lines: extrapolations based on deployment average), and (c,d) extrapolation to light using light-flux relationships measured in different seasons. GPP: gross primary production; $R$ : respiration; NEM: net ecosystem metabolism 
$-0.24 \mathrm{~kg} \mathrm{C} \mathrm{m}^{-2} \mathrm{yr}^{-1}$, assuming $\mathrm{O}_{2}: \mathrm{CO}_{2}$ of 1.0 ) was needed to sustain the respiratory requirements of the reef community on an annual basis. Planktonic production is expected to be a major food source at this location, and the water column in our study region is highly productive, with pelagic $\mathrm{GPP}_{\text {annual }}$ of up to $\sim 0.17 \mathrm{~kg} \mathrm{C} \mathrm{m}^{-2} \mathrm{yr}^{-1}, R \sim 0.12 \mathrm{~kg} \mathrm{C} \mathrm{m}^{-2} \mathrm{yr}^{-1}$, and NEM $\sim 0.05 \mathrm{~kg} \mathrm{C} \mathrm{m}^{-2} \mathrm{yr}^{-1}$ (Kuparinen et al. 1984, Lignell 1990, Raateoja et al. 2004). The estimated mussel filtration rates of up to $5 \mathrm{~m}^{3} \mathrm{~m}^{-2} \mathrm{~d}^{-1}$ suggest that the mussels can filter a volume equivalent to the entire overlying water column at our study site (water depth: $5 \mathrm{~m}$ ) every $24 \mathrm{~h}$. By greatly enhancing the transfer rate of suspended particulate matter to the reef through active filtration, the mussels can access a larger pool of the pelagic GPP than would otherwise be available through passive settlement (sedimentation) alone. Furthermore, given the high reef filtration rates and $\mathrm{C}$ demand, horizontal advection of water masses over the reef is expected to be important for suspended particulate matter supply (Frechette et al. 1989). Mean horizontal flow velocities at the mussel bed of between $2.6 \pm 2.7$ and $5.1 \pm 3.5 \mathrm{~cm}$ $\mathrm{s}^{-1}$ (Table 1) suggest that the reef experiences an advection path of between 2.2 and $4.4 \mathrm{~km} \mathrm{~d}^{-1}$. Given that the spatial extent of the reef was just $\sim 20 \mathrm{~m}$ in length, advection would alleviate stagnation by preventing the reef from being exposed to the same water mass for prolonged time periods.

Based on a bottom-up approach of computing macrofauna community respiration from biomass, Rodil et al. (2020) estimated that macrofauna respiration at our mussel reef site comprised $44 \%$ of the total $R_{\text {annual, }}$ with the latter determined from the eddy covariance fluxes. This value compares well with wider observations from shelf sediments that identified fauna as a key component of benthic $\mathrm{C}$ flows (Glud 2008, Middelburg 2018, Snelgrove et al. 2018). Based on these estimates, microbial communities living in association with the reef are therefore responsible for approximately half of the total reef organic $\mathrm{C}$ turnover. These high rates of microbial $\mathrm{C}$ turnover are likely sustained by the focusing effect created by the mussels, which enhances organic matter transfer onto the reef through biodeposition, enriching the seabed with $\mathrm{C}$ and nitrogen (N) (Norkko et al. 2001, Norling \& Kautsky 2007). We estimated biodeposition at our study site to be $\sim 0.05 \mathrm{~kg} \mathrm{C} \mathrm{m}^{-2}$ $\mathrm{yr}^{-1}$. Due to the underlying rocky substrate, $\mathrm{C}$ burial within the habitat is negligible, so remineralization and export are expected to be important $C$ flow pathways for biodeposits. Assuming that $25 \%$ of biodeposits are labile fractions of $\mathrm{C}$ that are rapidly remineralized within the reef within hours to a few days (Carlsson et al. 2010), most of the remaining $\sim 0.04 \mathrm{~kg}$ $\mathrm{C} \mathrm{m}^{-2} \mathrm{yr}^{-1}$ will be exported from the reef to the surrounding environment (Fig. 8). This C export value is an order of magnitude lower than that estimated for perennial macroalgal canopies of Fucus vesiculosus in the study area (Attard et al. 2019a). However, mussel reefs are $\sim 8$ times more abundant than macroalgal canopies in terms of areal coverage in this part of the Baltic Sea (Virtanen et al. 2018). Mussel biodeposits may therefore represent a regionally important $\mathrm{C}$ export flux of high nutritional value $(\mathrm{C}: \mathrm{N}=\sim 8)$ (Kautsky \& Evans 1987).

Annual monitoring data since 1996 indicates that M. trossulus reefs in this part of the Baltic Sea may persist for decades (Westerbom et al. 2019). However, on multiple occasions we observed large accumulations of dead and decaying $M$. trossulus in shallow waters of 1-2 m depth (Fig. 9). These observations often followed periods with elevated water temperature, and are likely caused by marine heatwaves, which are increasingly being observed in the study area (Siegel \& Gerth 2019). High water temperature is set against a backdrop of decreasing salinity in the Baltic, both of which result in the erosion of shallow mussel reefs (Westerbom et al. 2019). It is therefore

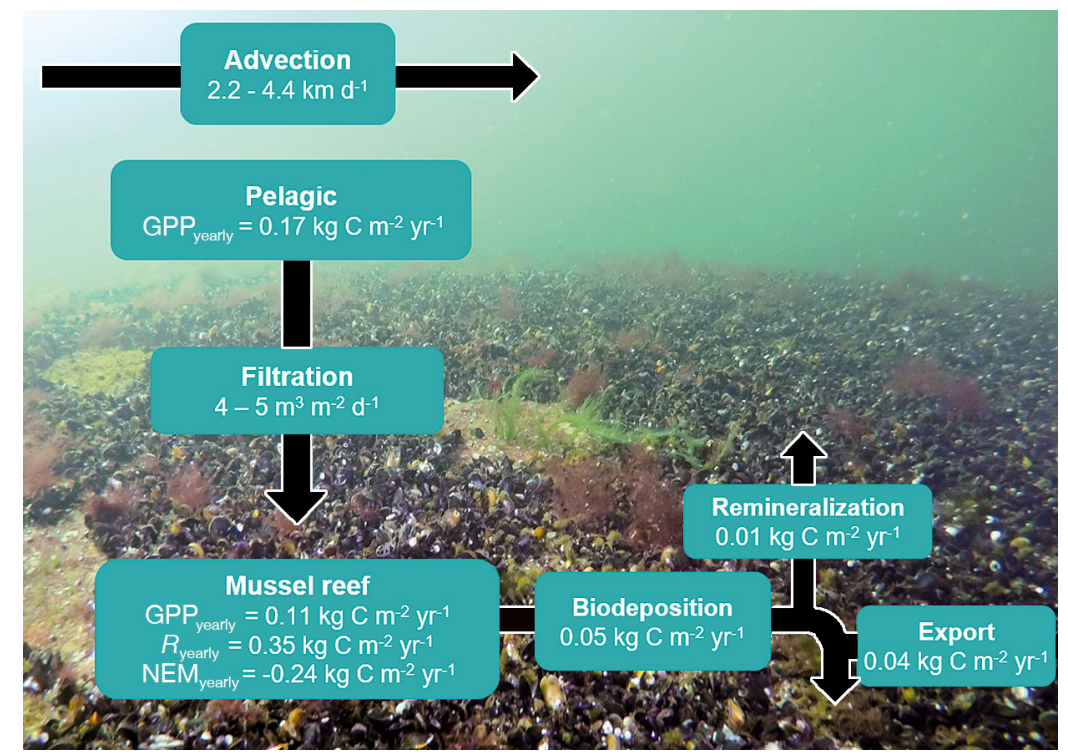

Fig. 8. Pathways of organic carbon flow at the rocky mussel reef; GPP: gross primary production; $R$ : respiration; NEM: net ecosystem metabolism 


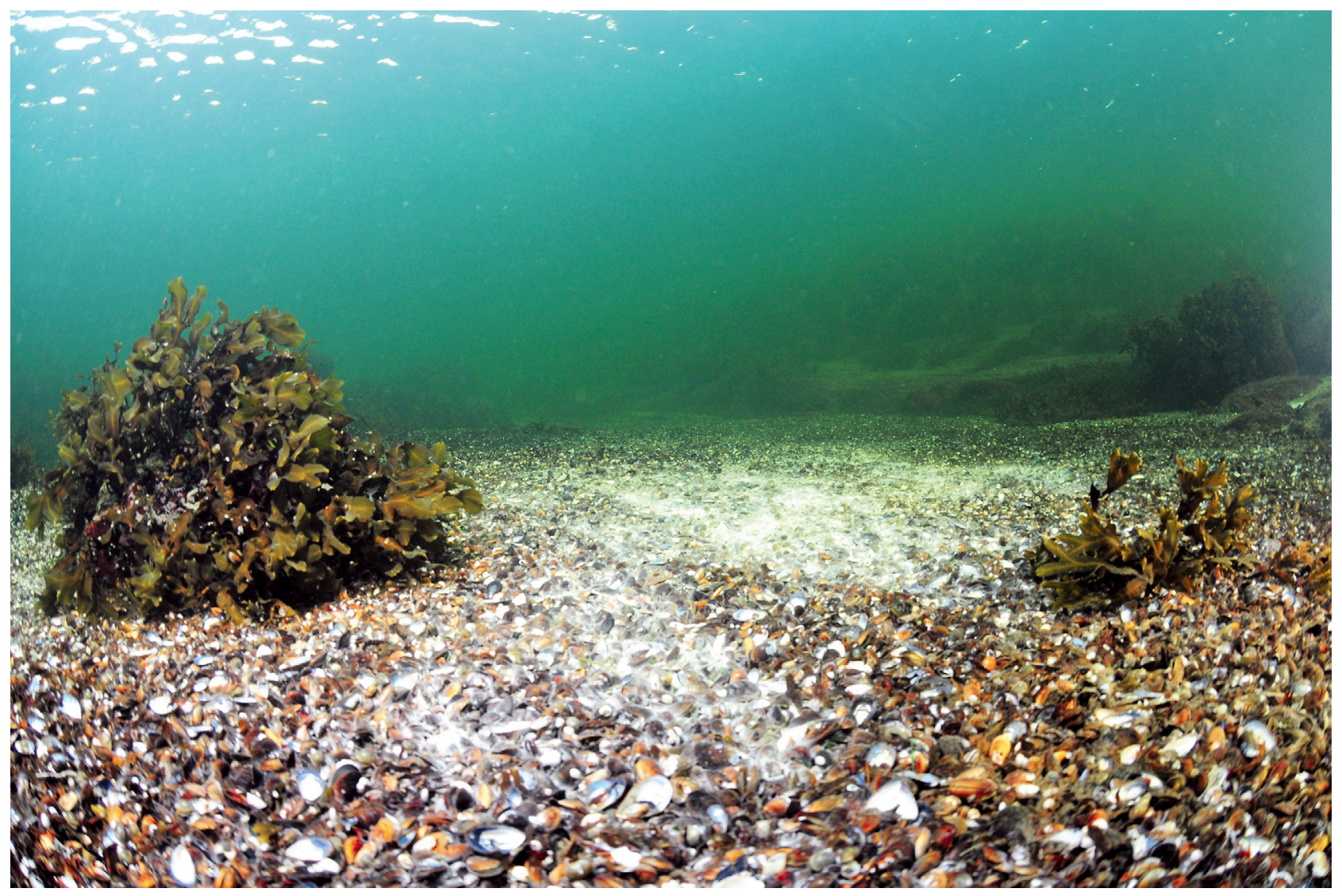

Fig. 9. A Mytilus trossulus mortality event following a heatwave nearby our study site at $\sim 1 \mathrm{~m}$ depth. Image shows large accumulations of dead and decaying $M$. trossulus that are colonized by white mats of sulphide-oxidizing bacteria

becoming increasingly important to assess C-flow pathways, to obtain a quantitative understanding of how mussel reefs function, and how the ecosystems they form part of could change in their absence.

Acknowledgements. Colleagues at the Tvärminne Zoological Station provided excellent support. In particular, we acknowledge Veijo Kinnunen, Hanna Halonen, Göran Lundberg, Kim Jaatinen, Camilla Gustafsson, Joanna Norkko, the Benthic Ecology team, and the secretariat for their help with planning and logistics. Anni Glud at the University of Southern Denmark constructed the oxygen microsensors used in this study. Elina Virtanen at the Finnish Environmental Institute (SYKE) provided habitat extent data. The Walter and Andrée de Nottbeck Foundation supported this work through a postdoctoral fellowship to K.M.A. and through a senior research fellowship to R.N.G. This study utilized research infrastructure facilities provided by FINMARI (Finnish Marine Research Infrastructure network, The Academy of Finland, project ID 283417). Further funding for this project was provided by research grants from The Academy of Finland (project ID 294853), the University of Helsinki and Stockholm University strategic fund for collaborative research, the European Commission through HADES-ERC (project ID 669947) and ATLAS (project ID 678760), and from the US National Science Foundation (OCE-1061364, OCE-1334848).

\section{LITERATURE CITED}

*Attard KM, Glud RN, McGinnis DF, Rysgaard S (2014) Seasonal rates of benthic primary production in a Greenland fjord measured by aquatic eddy correlation. Limnol Oceanogr 59:1555-1569

* Attard KM, Stahl H, Kamenos NA, Turner G, Burdett HL, Glud RN (2015) Benthic oxygen exchange in a live coralline algal bed and an adjacent sandy habitat: an eddy covariance study. Mar Ecol Prog Ser 535:99-115

* Attard KM, Rodil IF, Berg P, Norkko J, Norkko A, Glud RN (2019a) Seasonal metabolism and carbon export potential of a key coastal habitat: the perennial canopy-forming macroalga Fucus vesiculosus. Limnol Oceanogr 64: 149-164

* Attard KM, Rodil IF, Glud RN, Berg P, Norkko J, Norkko A (2019b) Seasonal ecosystem metabolism across shallow benthic habitats measured by aquatic eddy covariance. Limnol Oceanogr Lett 4:79-86

* Bayley DTI, Mogg AOM, Koldewey H, Purvis A (2019) Capturing complexity: field-testing the use of 'structure from motion' derived virtual models to replicate standard measures of reef physical structure. PeerJ 7:e6540

* Berg P, Huettel M (2008) Monitoring the seafloor using the noninvasive eddy correlation technique: integrated benthic exchange dynamics. Oceanography (Wash DC) 21: 164-167

Berg P, Røy H, Janssen F, Meyer V, Jorgensen BB, Huettel 
M, de Beer D (2003) Oxygen uptake by aquatic sediments measured with a novel non-invasive eddy-correlation technique. Mar Ecol Prog Ser 261:75-83

Berg P, Røy H, Wiberg PL (2007) Eddy correlation flux measurements: the sediment surface area that contributes to the flux. Limnol Oceanogr 52:1672-1684

Berg P, Long MH, Huettel M, Rheuban JE and others (2013) Eddy correlation measurements of oxygen fluxes in permeable sediments exposed to varying current flow and light. Limnol Oceanogr 58:1329-1343

Berg P, Reimers CE, Rosman JH, Huettel M, Delgard ML, Reidenbach MA, Ozkan-Haller HT (2015) Technical note: time lag correction of aquatic eddy covariance data measured in the presence of waves. Biogeosciences 12: 6721-6735

Berg P, Koopmans DJ, Huettel M, Li H, Mori K, Wuest A (2016) A new robust oxygen-temperature sensor for aquatic eddy covariance measurements. Limnol Oceanogr Methods 14:151-167

Berg P, Delgard ML, Glud RN, Huettel M, Reimers CE, Pace ML (2017) Non-invasive flux measurements at the benthic interface: the aquatic eddy covariance technique. Limnol Oceanogr e-Lectures 7:1-50

Brey T (2001) Population dynamics in benthic invertebrates: a virtual handbook. Alfred Wegener Institute for Polar and Marine Research, Bremerhaven

Butman CA, Frechette M, Geyer WR, Starczak VR (1994) Flume experiments on food-supply to the blue mussel Mytilus edulis as a function of boundary-layer flow. Limnol Oceanogr 39:1755-1768

Carlsson MS, Glud RN, Petersen JK (2010) Degradation of mussel (Mytilus edulis) fecal pellets released from hanging long-lines upon sinking and after settling at the sediment. Can J Fish Aquat Sci 67:1376-1387

Commito JA, Rusignuolo BR (2000) Structural complexity in mussel beds: the fractal geometry of surface topography. J Exp Mar Biol Ecol 255:133-152

Donis D, Holtappels M, Noss C, Cathalot C and others (2015) An assessment of the precision and confidence of aquatic eddy correlation measurements. J Atmos Ocean Technol 32:642-655

* Elser JJ, Bracken MES, Cleland EE, Gruner DS and others (2007) Global analysis of nitrogen and phosphorus limitation of primary producers in freshwater, marine and terrestrial ecosystems. Ecol Lett 10:1135-1142

F Frechette M, Butman CA, Geyer WR (1989) The importance of boundary-layer flows in supplying phytoplankton to the benthic suspension feeder, Mytilus edulis. Limnol Oceanogr 34:19-36

Glud RN (2008) Oxygen dynamics of marine sediments. Mar Biol Res 4:243-289

Gundersen JK, Ramsing NB, Glud RN (1998) Predicting the signal of $\mathrm{O}_{2}$ microsensors from physical dimensions, temperature, salinity, and $\mathrm{O}_{2}$ concentration. Limnol Oceanogr 43:1932-1937

Heisterkamp IM, Schramm A, Larsen LH, Svenningsen NB, Lavik G, de Beer D, Stief P (2013) Shell biofilm-associated nitrous oxide production in marine molluscs: processes, precursors and relative importance. Environ Microbiol 15:1943-1955

Hilbish TJ, Mullinax A, Dolven SI, Meyer A, Koehn RK, Rawson PD (2000) Origin of the antitropical distribution pattern in marine mussels (Mytilus spp.): routes and timing of transequatorial migration. Mar Biol 136:69-77

*Hofmann GE, Somero GN (1995) Evidence for protein dam- age at environmental temperatures: seasonal changes in levels of ubiquitin conjugates and hsp70 in the intertidal mussel Mytilus trossulus. J Exp Biol 198:1509-1518

Holtappels M, Noss C, Hancke K, Cathalot C, McGinnis DF, Lorke A, Glud RN (2015) Aquatic eddy correlation: quantifying the artificial flux caused by stirring-sensitive $\mathrm{O}_{2}$ sensors. PLOS ONE 10:e0116564

* Hume AC, Berg P, McGlathery KJ (2011) Dissolved oxygen fluxes and ecosystem metabolism in an eelgrass (Zostera marina) meadow measured with the eddy correlation technique. Limnol Oceanogr 56:86-96

Kautsky H (1989) Quantitative distribution of plant and animal communities of the phytobenthic zone in the Baltic Sea. Contrib Askö Lab Univ Stockholm 35:1-80

Kautsky N, Evans S (1987) Role of biodeposition by Mytilus edulis in the circulation of matter and nutrients in a Baltic coastal ecosystem. Mar Ecol Prog Ser 38:201-212

Kautsky N, Tedengren M (1992) Ecophysiological strategies in Baltic Sea invertebrates. In: Bjørnestat E, Hagerman L, Jensen K (eds) Proc $12^{\text {th }}$ Baltic marine biologists symp, 25-30 August 1991, Helsingør. Olsen \& Olsen, Fredensborg, p 91-96

Kautsky N, Wallentinus I (1980) Nutrient release from a Baltic Mytilus red algal community and its role in benthic and pelagic productivity. Ophelia Suppl 1:17-30

Kotta J, Herkul K, Kotta I, Orav-Kotta H, Lauringson V (2009) Effects of the suspension feeding mussel Mytilus trossulus on a brackish water macroalgal and associated invertebrate community. Mar Ecol 30:56-64

Kuparinen J, Leppanen JM, Sarvala J, Sundberg A, Virtanen A (1984) Production and utilization of organic matter in a Baltic ecosystem off Tvärminne, southwest coast of Finland. Rapp P-V Reùn Cons Int Explor Mer 183:180-192

K Lignell R (1990) Excretion of organic carbon by phytoplankton: its relation to algal biomass, primary productivity and bacterial secondary productivity in the Baltic Sea. Mar Ecol Prog Ser 68:85-99

KLorke A, McGinnis DF, Maeck A (2013) Eddy-correlation measurements of benthic fluxes under complex flow conditions: effects of coordinate transformations and averaging time scales. Limnol Oceanogr Methods 11:425-437

* Lorrai C, McGinnis DF, Berg P, Brand A, Wuest A (2010) Application of oxygen eddy correlation in aquatic systems. J Atmos Ocean Technol 27:1533-1546

* McGinnis DF, Cherednichenko S, Sommer S, Berg P and others (2011) Simple, robust eddy correlation amplifier for aquatic dissolved oxygen and hydrogen sulfide flux measurements. Limnol Oceanogr Methods 9:340-347

* McGinnis DF, Sommer S, Lorke A, Glud RN, Linke P (2014) Quantifying tidally driven benthic oxygen exchange across permeable sediments: an aquatic eddy correlation study. J Geophys Res Oceans 119:6918-6932

* Meier HEM, Hordoir R, Andersson HC, Dieterich C and others (2012) Modeling the combined impact of changing climate and changing nutrient loads on the Baltic Sea environment in an ensemble of transient simulations for 1961-2099. Clim Dyn 39:2421-2441

Middelburg JJ (2018) Reviews and syntheses: to the bottom of carbon processing at the seafloor. Biogeosciences 15: 413-427

Miller DC, Geider RJ, MacIntyre HL (1996) Microphytobenthos: the ecological role of the 'secret garden' of unvegetated, shallow-water marine habitats. II. Role in sediment stability and shallow-water food webs. Estuaries 19: 202-212 
Nishizaki M, Ackerman JD (2017) Mussels blow rings: jet behavior affects local mixing. Limnol Oceanogr 62: 125-136

Norkko A, Hewitt JE, Thrush SF, Funnell GA (2001) Benthic-pelagic coupling and suspension-feeding bivalves: linking site-specific sediment flux and biodeposition to benthic community structure. Limnol Oceanogr 46: 2067-2072

Norling P, Kautsky N (2007) Structural and functional effects of Mytilus edulis on diversity of associated species and ecosystem functioning. Mar Ecol Prog Ser 351:163-175

Norling P, Kautsky N (2008) Patches of the mussel Mytilus sp. are islands of high biodiversity in subtidal sediment habitats in the Baltic Sea. Aquat Biol 4:75-87

Okumus I, Stirling HP (1998) Seasonal variations in the meat weight, condition index and biochemical composition of mussels (Mytilus edulis L.) in suspended culture in two Scottish sea lochs. Aquaculture 159:249-261

Ost M, Kilpi M (1998) Blue mussels Mytilus edulis in the Baltic: good news for foraging eiders Somateria mollissima. Wildl Biol 4:81-89

* Prins TC, Smaal AC (1994) The role of the blue mussel Mytilus edulis in the cycling of nutrients in the Oosterschelde Estuary (the Netherlands). Hydrobiologia 282: 413-429

Raateoja M, Seppälä J, Kuosa H (2004) Bio-optical modelling of primary production in the SW Finnish coastal zone, Baltic Sea: fast repetition rate fluorometry in Case 2 waters. Mar Ecol Prog Ser 267:9-26

Rayssac N, Pernet F, Lacasse O, Tremblay R (2010) Temperature effect on survival, growth, and triacylglycerol content during the early ontogeny of Mytilus edulis and $M$. trossulus. Mar Ecol Prog Ser 417:183-191

Rheuban JE, Berg P (2013) The effects of spatial and temporal variability at the sediment surface on aquatic eddy correlation flux measurements. Limnol Oceanogr Methods 11:351-359

Rheuban JE, Berg P, McGlathery KJ (2014) Ecosystem metabolism along a colonization gradient of eelgrass (Zostera marina) measured by eddy correlation. Limnol Oceanogr 59:1376-1387

Riisgard HU, Luskow F, Pleissner D, Lundgreen K, Lopez MAP (2013) Effect of salinity on filtration rates of mussels Mytilus edulis with special emphasis on dwarfed mussels from the low-saline Central Baltic Sea. Helgol Mar Res 67:591-598

Riisgard HU, Larsen PS, Pleissner D (2014) Allometric equations for maximum filtration rate in blue mussels Mytilus edulis and importance of condition index. Helgol Mar Res 68:193-198

Rodil IF, Attard KM, Norkko J, Glud RN, Norkko A (2020) Estimating respiration rates and secondary production of macrobenthic communities across coastal habitats with

Editorial responsibility: Lisandro Benedetti-Cecchi, Pisa, Italy contrasting structural biodiversity. Ecosystems 23:630-647

* Rodil IF, Attard KM, Norkko J, Glud RN, Norkko A (2019) Towards a sampling design for characterizing habitatspecific benthic biodiversity related to oxygen flux dynamics using aquatic eddy covariance. PLOS ONE 14: e0211673

Rumohr H, Brey T, Ankar S (1987) A compilation of biometric conversion factors for benthic invertebrates of the Baltic Sea. The Baltic Marine Biologists Publication No. 9

* Saurel C, Gascoigne JC, Palmer MR, Kaiser MJ (2007) In situ mussel feeding behavior in relation to multiple environmental factors: regulation through food concentration and tidal conditions. Limnol Oceanogr 52:1919-1929

Siegel H, Gerth M (2019) Sea surface temperature in the Baltic Sea in 2018. https://helcom.fi/baltic-sea-trends/ environment-fact-sheets/hydrography/sea-surfacetemperature-in-the-baltic-sea-in-2018/ (accessed 11 June 2019)

Snelgrove PVR, Soetaert K, Solan M, Thrush S and others (2018) Global carbon cycling on a heterogeneous seafloor. Trends Ecol Evol 33:96-105

Virtanen EA, Viitasalo M, Lappatainen J, Moilanen A (2018) Evaluation, gap analysis, and potential expansion of the Finnish marine protected area network. Front Mar Sci 5: 402

Volaric MP, Berg P, Reidenbach MA (2018) Oxygen metabolism of intertidal oyster reefs measured by aquatic eddy covariance. Mar Ecol Prog Ser 599:75-91

Vuorinen I, Hanninen J, Rajasilta M, Laine P and others (2015) Scenario simulations of future salinity and ecological consequences in the Baltic Sea and adjacent North Sea areas-implications for environmental monitoring. Ecol Indic 50:196-205

Westerbom M, Kilpi M, Mustonen O (2002) Blue mussels, Mytilus edulis at the edge of the range: population structure, growth and biomass along a salinity gradient in the north-eastern Baltic Sea. Mar Biol 140:991-999

WWesterbom M, Mustonen O, Kilpi M (2008) Distribution of a marginal population of Mytilus edulis: responses to biotic and abiotic processes at different spatial scales. Mar Biol 153:1153-1164

Westerbom M, Lappalainen A, Mustonen O, Norkko A (2018) Trophic overlap between expanding and contracting fish predators in a range margin undergoing change. Sci Rep 8:7895

*Westerbom M, Mustonen O, Jaatinen K, Kilpi M, Norkko A (2019) Population dynamics at the range margin: implications of climate change on sublittoral blue mussels (Mytilus trossulus). Front Mar Sci 6:292

*Wijsman JWM, Herman PMJ, Gomoiu MT (1999) Spatial distribution in sediment characteristics and benthic activity on the northwestern Black Sea shelf. Mar Ecol Prog Ser 181:25-39

Submitted: October 29, 2019; Accepted: May 18, 2020 Proofs received from author(s): July 3, 2020 